\title{
Dermatofibroma Frequent Disease, Uncommon Location
}

\section{R.Chaoui *, M. Bennani, S.Oukarfi, S.Elloudi, H.Baybay, FZ.Mernissi}

Department of Dermatology, Hassan II University Hospital Center, Morocco

*Corresponding author: Chaoui Rhizlane, Department of Dermatology, Hassan II University Hospital Center, Morocco.

Email: chaoui.rhizlane@gmail.com

Received date: December 16, 2019; Accepted date: December 30, 2019; Published date: January 02, 2020

Citation: R.Chaoui, M. Bennani, S.Oukarfi, S.Elloudi, H.Baybay, FZ.Mernissi. Dermatofibroma Frequent Disease, Uncommon Location Clinical Medical Reviews and Reports, 2(1); DOI: 10.31579/2690-8794/003

Copyright: (C) 2019 Walid bai. This is an open access article distributed under the Creative Commons Attribution License, which permits unrestricted use, distribution, and reproduction in any medium, provided the original work is properly cited.

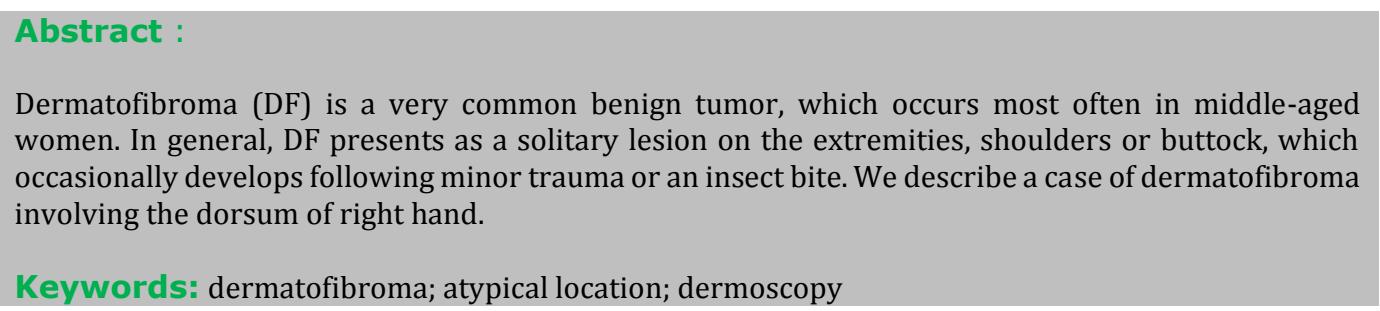

\section{Introduction:}

Dermatofibromas is common tumor of the skin with considerable clinical and histological variability.

It presents as a solitary lesion on the extremities, shoulders or buttock, in middle-aged women.

We report a case of dermatofibroma affecting the dorsum of right hand.

\section{Observation:}

A 30-year-old healthy women presented with an 8 month history of an erythematous lesion, asymptomatic, gradually increasing in size on the dorsum of the right hand.

The dermatological examination revealed a single, well-defined erythematous papule measuring $5 * 4 \mathrm{~mm}$ with firm consistency involving the dorsum of the right hand (figure 1). Clinical differential diagnosis of wart was considered. A dermoscopic evaluation showed peripheral pigmented network and central white patch (figure2).

A total excision of the lesion was performed and histopathologic examination revealed a dermal tumor poorly limited, consisting of fusiform cells arranged in short and storiform bundles, nuclear atypia and mitotic activity were not (figure 3 ).

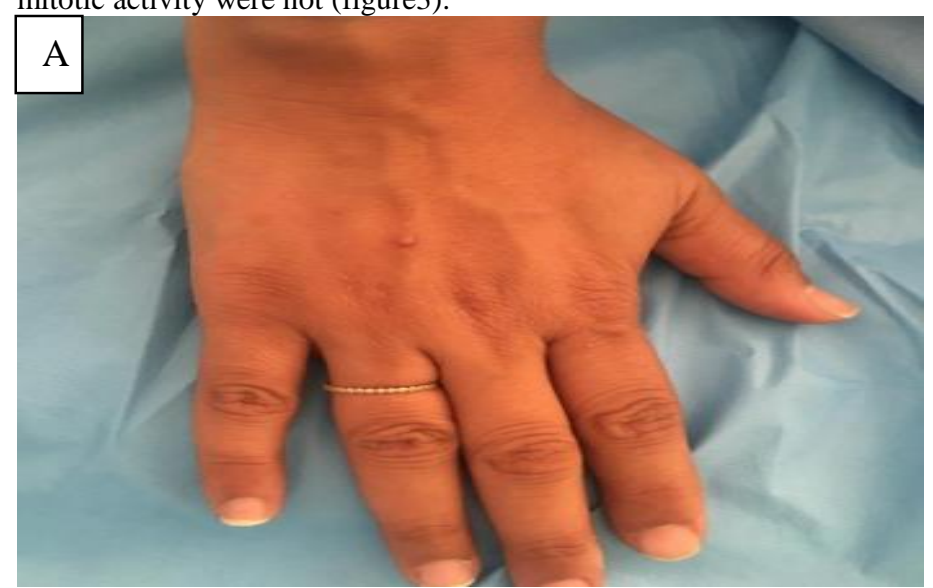

A diagnosis of dermatofibroma was considered on clinical, dermoscopic, and histopathological correlation.

\section{B}
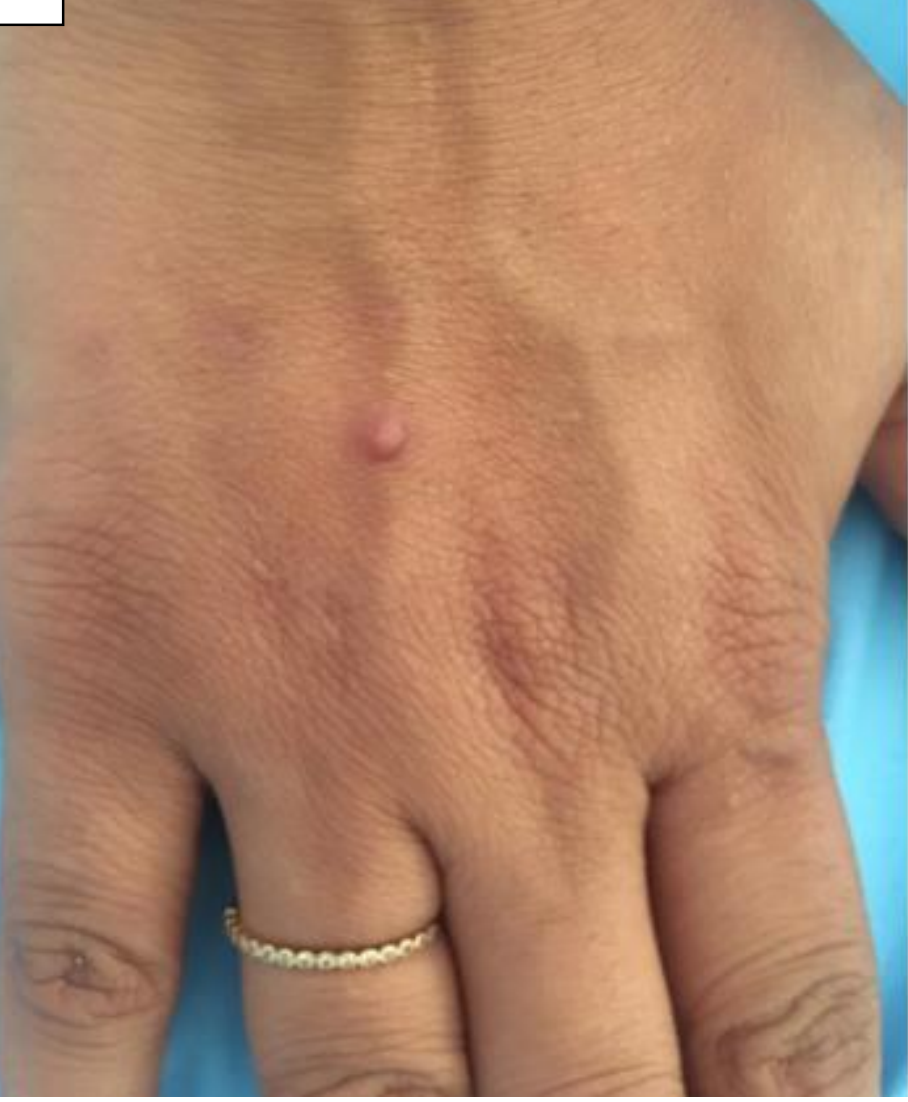

Figure 1: A, B : Single well-circumscribed erythematous papule with firm consistency on the dorsum of the right hand. 


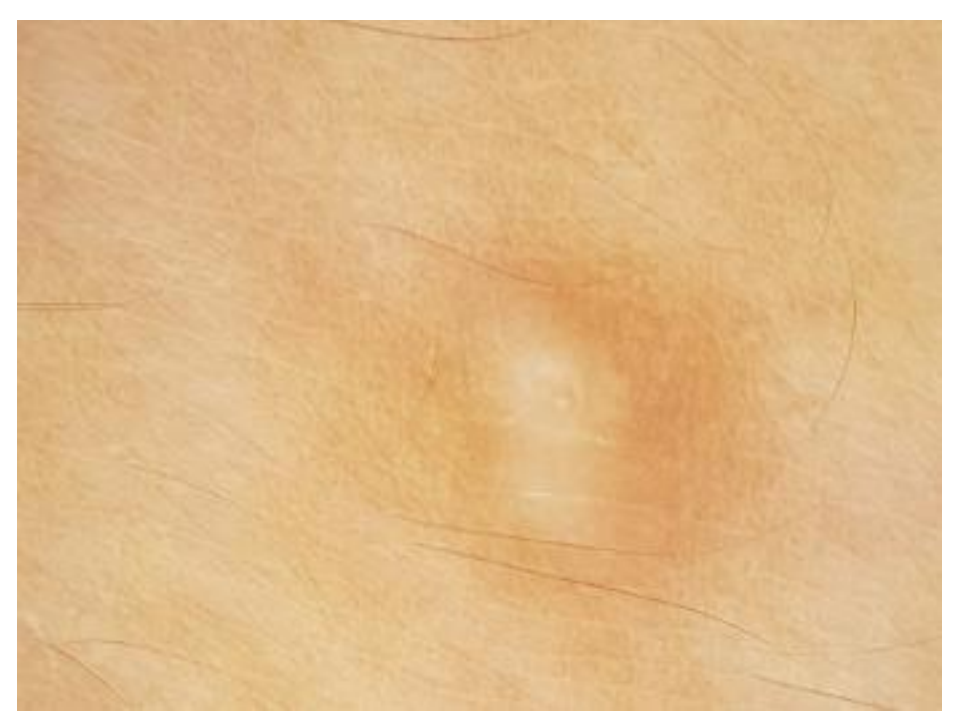

Figure 2: dermoscopy showed peripheral pigmented network with central white patch.

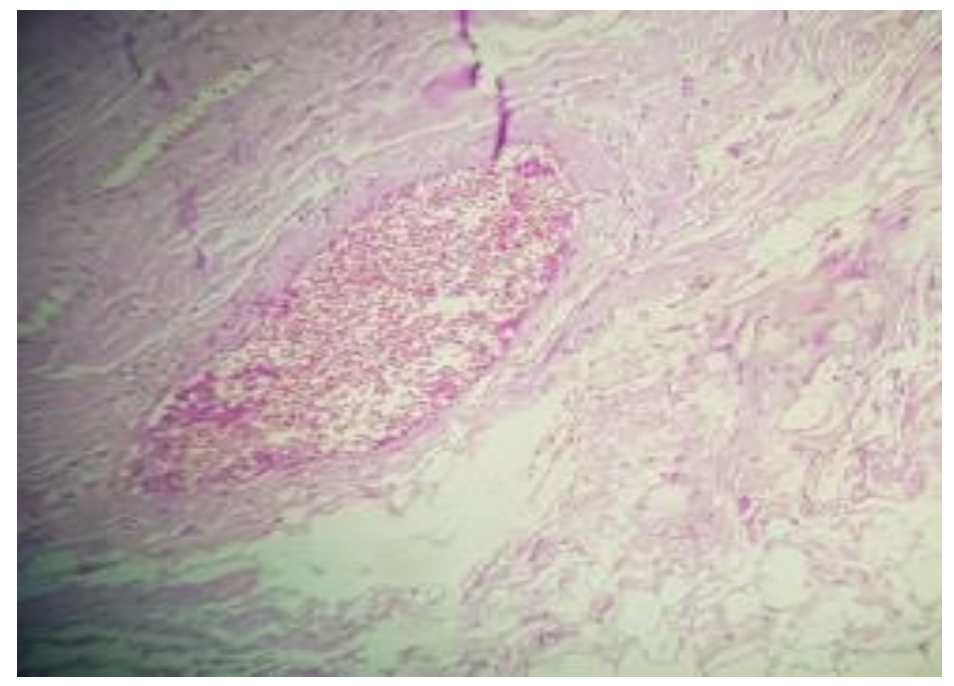

Figure 3: dermal tumor, consisting of fusiform cells arranged in short and storiform bundles.

\section{Discussion:}

Dermatofibroma is a common benign fibrohistiocytic tumor which uncommonly involves the hands. It occurs most often in middle-aged women. It located predominantly on the limbs and shoulder. DF presented generally as a single or multiple firm reddish-brown nodules [1].

Different variants of dermatofibroma have been found and they are essentially distinguished by their clinical and histopathological features like common fibrous histiocytoma, aneurysmal,hemosiderotic, epithelioid, cellular, lipidized, atrophic and clear cell[2].

Several dermoscopic patterns of dermatofibroma are described, of which the most common is central white scar-like patch with pigment network at the periphery [3].

The classical histopathological features include a poorly circumscribed proliferation of spindle-shaped fibroblasts or histiocytes arranged in sheets or interlocking strands with a storiform pattern and collagen trapping [4].

Surgical excision is the recommended management with margin of 3-mm [5].

\section{Conclusion:}

Dermatofibroma (DF) is a common benign tumor, which affects frequently the lower extremity .Hand location remains exceptional.

\section{Conflict of interest.}

The authors do not declare any conflict of interest.

\section{Contributions of authors}

All authors contributed to the writing of this article. The authors also state that they have read and approved the final version

\section{References}

1. Singh S, Patra S, Bhari N. (2019) Indian Dermatol Online J. JanFeb;10(1):94-95.

2. Alves JVP, Matos DM, Barreiros HF, Bártolo (2014) Variants of dermatofibroma - a histopathological study. Anais Brasileiros de Dermatologia, 89(3), 472-477.

3. Kelati A, Aqil N, Baybay H, Gallouj S, \& Mernissi FZ (2017) Beyond classic dermoscopic patterns of dermatofibromas: a prospective research study. Journal of Medical Case Reports, 11(1).

4. Lee M, Lee W, Jung J, Won C, Chang S et al. (2015) Clinical and histological patterns of dermatofibroma without gross skin surface change: A comparative study with conventional dermatofibroma. Indian Journal of Dermatology, Venereology, and Leprology, 81(3), 263.

5. Kim HJ, Kim I-H (2015) A 3-mm margin completely removes dermatofibromas: A study of 151 cases. Dermatol Surg. 41:2836. 